\title{
清酒の着色について (I)
}

清酒の一般成分と着色の程度

西川久雄, 佐 藤 信

(昭和 33 年 9 月 12 日受理)

\section{まえがき}

食品の褐色化は, その色感が及ぼす心理的な効果と, 褐色化に伴なう香味の変化と二様の意味で重要であ る。近年食品の褐色化についての報告は, 醬油 ${ }^{1)}$, 味淋 ${ }^{2}$, 乳製品 ${ }^{3)}$, 果汁 ${ }^{4}$ 等の多方面にみられるが, 清酒 飞ついての報告は少ない。

食品の褐色化の内容については, 酸化によらない变色として, 含窒素化合物と糖類との反応, 含窒素化合 物々有機酸との反応, 糖類と有機酸との反応, 有機酸のみに上る反応等が知られ, 又酸化に上る変色として は酵素作用による反応と非酵素的な反応とが考兄られており，更に清酒については鉄その他の無機イオンに よる変色もよく知られている。

一方清酒の場合製造過程から見ると, 原料から移行する色, 醸造中の着色の変化, 火入及び貯蔵中の着色 の三段階に分けて考劣るのが妥当と思われる。筆者らは, 先ず最も直接的な問題として火入及び貯蔵中の着 色をとりあげて，清酒一般成分と着色との関係を統計的に考察したのでここに報告する。

\section{実験}

\section{試料}

東京局管内 15 力所の酒造場から普通アル添酒 13 点及び精米歩合 $70 \%$ 以下の吟酾酒 14 点, 計 27 点 (いずれも滓引済, 但し火入及び炭素濾過をしない生酒)の寄贈を受け, これを試料とした。

\section{火父}

各試料 $300 \mathrm{cc}$ を 3 デシ瓶にとり, コルク栓を附して $55^{\circ} \mathrm{C}$ で 5 分間保つた後すみやかに放冷し，室温で 瞕室に眝蔵した。

\section{着色度の測定}

各試料の火入前 ( 5 月 19 日測定) の着色度, 及び火入直後 (火入後 24 時間測定) ならびに半年間室温, 暗室貯蔵後 (11 月 11 日測定) の着色の增加度を日立 EPO-B 型光電比色計によつて, $10 \mathrm{~mm}$ のセル用 い,フィルター No. 43 による透過度（蒸溜水 100 に対する 100 分率）で表示した。

\section{結 果}

（A）火入前試料 27 点の透過度と各種成分の関係を, 第 1 4 図に示した。この場合, 吟䁔酒と普通酒

第 1 図

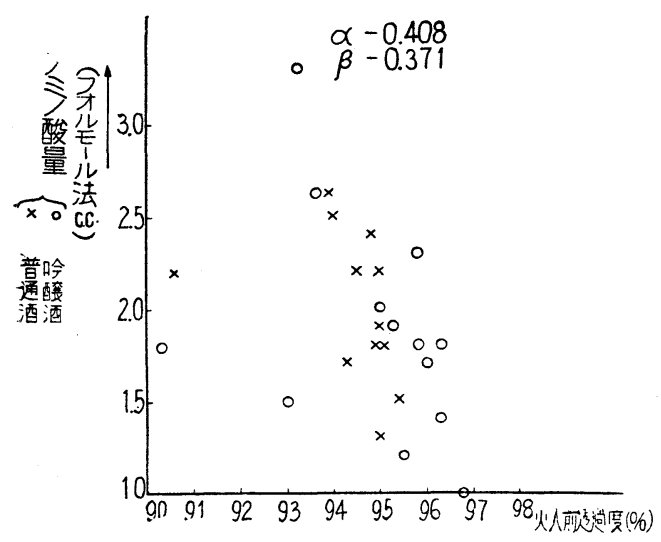

第 2 図




は異質のものとして区別する方が適当と考号られるので，図中吟醸酒は○印で，普通酒は×印で区別してあ る。表中の数值は相関係数を示し， $\alpha, \beta$ の記号は夫々吟醇酒及び普通酒を岕わす。
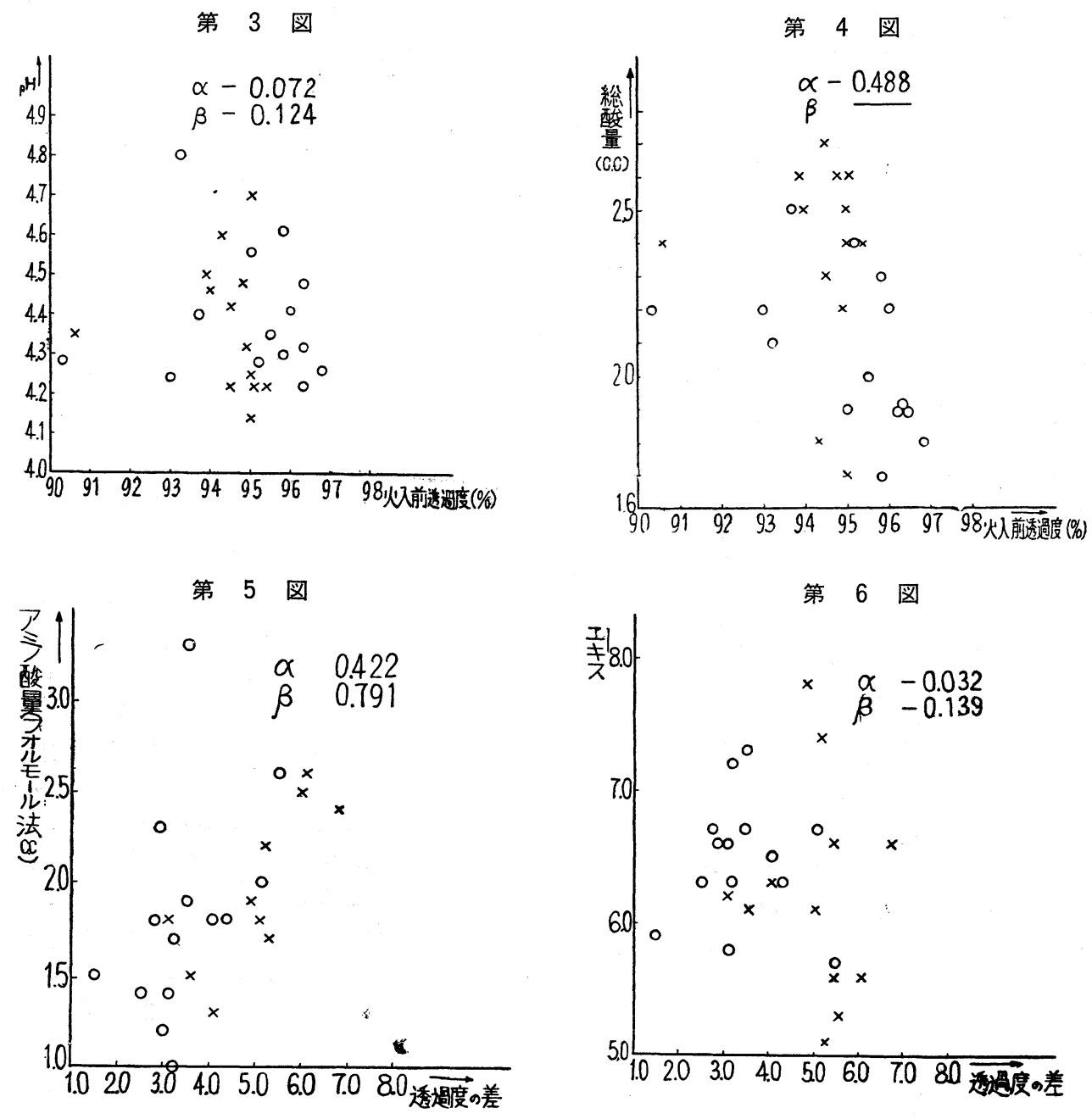

第 7 网

第 8 図
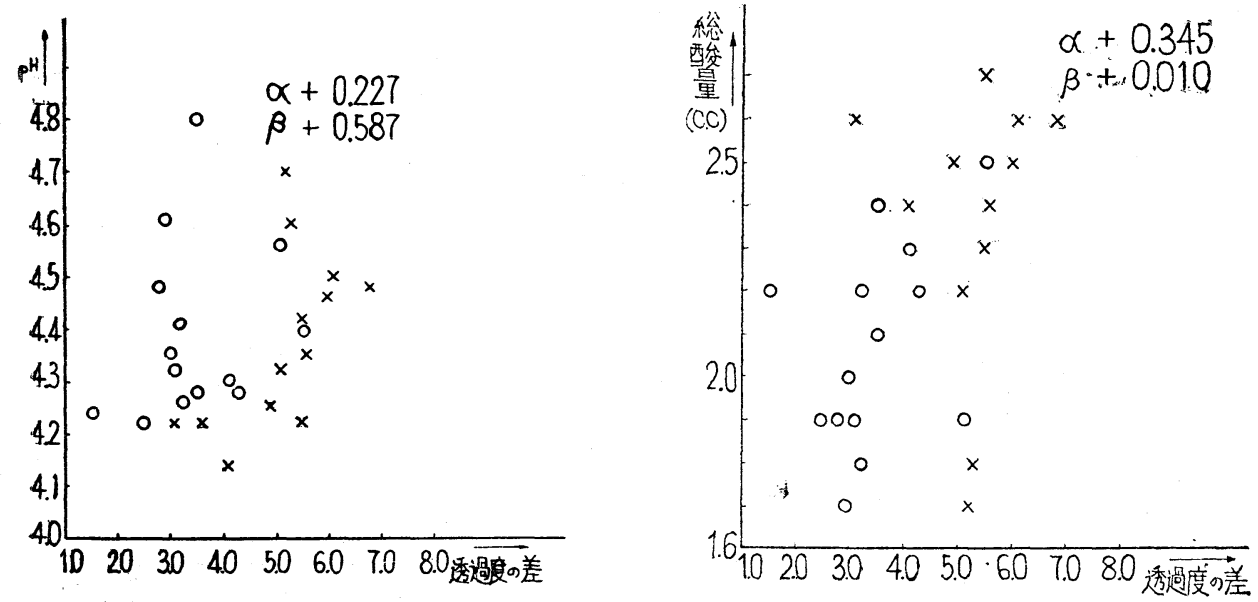
（B） 火入前の透過度と貯蔵後の透過度との差（即ち着色度の増加）飞各種成分との相関図を第 $5 \sim 8$ 図 に示す。

更に以上の相関度をまとめると第 1 表のよ 5 にる。表中の值は相関係数を示し, * は $5 \%$ 有意, **は $1 \%$ 有意である事を示す。

成 分
火入前試料の着色度 $\left\{\begin{array}{l}\text { 吟醸酒 } \\ \text { 普通酒 }\end{array}\right.$
貯蔵中の着色增加量 $\left\{\begin{array}{l}\text { 吟醸酒 } \\ \text { 普通酒 }\end{array}\right.$

\begin{tabular}{|c|c|c|c|}
\hline 第 & 表 & & \\
\hline アミノ酸量 & エキス量 & $\mathrm{pH}$ & 総酸量 \\
\hline-0.408 & 0.296 & -0.072 & -0.488 \\
\hline-0.371 & 0.503 & -0.124 & 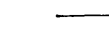 \\
\hline 0.422 & -0.032 & 0.227 & 0.345 \\
\hline$* * 0.791$ & -0.139 & $* 0.587$ & 0.010 \\
\hline
\end{tabular}

\section{結果とその考案}

以上の結果について考察すれば,

(A) 清酒の火入前の着色度と各種成分との相関については次の傾向がみられた。

（イ）アミノ酸量の多い清酒ほど着色度が大きい(第 1 図)。

(ロ) エキス分の少ない清酒程着色度が大きい(第 2 図)。

(八) $\mathrm{pH}$ と着色度，総酸量と着色度の間には明膫な関係は認められない（第 3,4 図）。

以上の関倸は原料から移行する色及び製造中に生成又は消失する色と生成酒の成分の関係を一応示すと考 えられるが, 相関係数が小さいこと及びアルコール添加量についての資料が不充分であつたので, その結論 をそのまま受け入れることは出来ない。

（B）火入及び貯蔵中の着色の増加量と清酒成分との関係を示す第 5 8 図から次の結論が得られる。

（イ）アミノ酸含量の大きい清酒程, 貯蔵中の着色が大である(第 5 図)。但し相関係数は普通酒の場合 $5 \%$ 有意であるが，吟䤑酒ではわずかに $5 \%$ 水準に達しない(第 1 表参照)。

(ヨ) エキス量と貯蔵中の着色度の増加との間には全く関係がみられないが(第 6 図), これは甘い酒程色 がつき易いという従来の通念が正しくないことを示している。糖が着色の内容に関係していることは充分予 想されることであるので，一定量以上の糖の存在が無関係であることを示するのと考兄られ。

(ハ) $\mathrm{pH}$ の高い清酒程貯蔵中の着色度が大きい(第 7 図)。このことは普通酒の場合特に顕著に見られ た。

（二）総酸量の大きい清酒程眝蔵中の着色度が大きい（第 8 困)。但し，この関俰はさほど顕著ではない。

（ホ）以上の結論で貯蔵中の着色度の増加には， $\mathrm{pH}$ とアミノ酸量及び総酸量の 3 つの要因が関係するこ とを知つたが, 一方これらの要因相互の間にも相関がみられる。

即ち，アミノ酸量と $\mathrm{pH}$ との関係は第 9 図に示すように, 両者の間に大きな正の相関がある。更に, 総酸 量とアミノ酸量との関係は第 10 図に示すよ5に正の相関をもつている。(但し統計的に有意ではない。)

従つて, 貯蔵中の着色度の増加に対してこれらの要因が各々直接的な関係をもつのか, 或は 3 つの要因の

うち 1 部の要因が直接的な関係をもつために残りの要因が見掛上の関係をもつようになるのかは，これだけ の実験では不明である。

総括

清酒の火入及び眝蔵中の着色度の增加に関係する要因を探すために, 生酒 27 点を火入貯蔵してその着色 度の增加と, 清酒の一般成分との関係を統計的に考察した。

この結果,

（1）貯蔵中の着色度の增加には, エキス含量（その大部分は糖類）は無関係であること, 従つて従来の 甘い酒程色がつき易いという通念は正しくないこと。

（2）貯蔵中の着色度の增加には，アミノ酸含量， $\mathrm{pH}$, 総酸量が関係すること。この5ち前 2 者の相関 係数は統計的に有意である。

（3）但しこれ等 3 要因相互の間にも正の関係があるため，これら要因と着色度の増加との関係がすべて 直接的であるか, 又は一部直接的で残りは見掛上のものであるかは本実験の範囲では明らかにし得なかつた こと等を知つた。

文献

1) 大亦正次郎, 上野照雄, 中川 泰：農化 29, 165, 215, 251, 256(1955) ; 酸工 34, 166, 173(1956)

2) 大亦正次郎, 上野照雄, 中川 泰: 醴工 34,173 (1956)

$3 ）$ 足立 達: 農化 $30,92,126,372,378,383$ (1956)

4) 野村男次: 醴工 34, 317 (1956)

今井 寛, 酒井宏美, 藤谷 健, 大西隆三: 農化 $31,161,165$ (1957)

5）村上英也, 河合美登利：本誌 51，549 (1946) ; 本誌 52，651，838，1005 (1957)

6) Bhatia B.S., Kapur N.S., Bhatia D.S. and Girdhari L.: Food Research, 21, 266 (1957)

\section{米麴のプロテアーゼに関する研究（第 3 報）}

尿素による酵素の変性

鈴木 明治, 布川弥太郎, 馬場 国 男

(昭和 33 年 10 月 15 日受理)

吾々は従来, 米麳プロテアーゼの組成についての研究に, 基質として Casein を使用して来たが, このも のは $\mathrm{pH}$ 3.7 5.3 の間で凝固沈澱する性質があり, 従つてプロテアーゼの $\mathrm{pH}$ 作用曲線も此の間ブランク にならざるを得ない恨がある。栗山等1 は可溶性澱粉を $1 \%$ 程度 Casein に予め混合し， pH 3.0 以下又は $\mathrm{pH} 7.0$ 以上としして著沸，溶解後 blender で攪找しながら所定の $\mathrm{pH}$ に調整して Casein の塊状凝固を 防ぐような方法を提出しているが，此の方法によつてもCasein が完全に溶解している訳ではないので果し て吾々の実験に利用出来るか否か不明である。

先きに K. Wallenfels ${ }^{2}$ が，溶解に $30 \%$ 程度の尿素を添加すれば Casein の凝固を阻止し得ることを報 じているので, 吾々は先ず此の方法に従つて, 米核プロテアーゼの $\mathrm{pH}$ 作用曲線を描いた所, 成る程従来の ブランクの部分を埋めることが出来たが，その代り今迄とは可成り趣きの異る曲線となつて現われた。この ことは基質たる Casein が尿素によつて変性を受けたことと同時に酵素も亦影響されたことを暗示するるの であるから，以下，これについて多少の検討を行つて報告することとした。

1）予備実験

先ず pH 4.0 及び 7.0 の Buffer による䤉素抽出液について, それが Casein 消化の際, 溶液濃度の 30 \%に相当するように尿素を加光, その他は常法に従つて $\mathrm{pH}$ 作用曲線を求めた処, 第 1 図に示す如き結果 を得た。即ち尿素無添加の時に較べて作用極大点が夫々 $\mathrm{pH} 3.0$ 附近から 5.5 附近へ, $\mathrm{pH} 6.5$ 及び 7.5 附近 から 5.5 附近へ移動して来ている。

2）尿素による酵素の変性 